\title{
Decreased macrophage release of TGF- $\beta$ and TIMP-1 in chronic obstructive
} pulmonary disease

\author{
A.R. Pons*, J. Sauleda\#, A. Noguera*, J. Pons", B. Barceló*, \\ A. Fuster ${ }^{\#}$ and A.G.N. Agustí ${ }^{\#}$
}

ABSTRACT: The present study tested the hypothesis that alveolar macrophages (AM) from patients with chronic obstructive pulmonary disease (COPD) release more pro-inflammatory and/ or less anti-inflammatory mediators than those from smokers with normal lung function and neversmokers.

AM were sorted by flow cytometry from bronchoalveolar lavage fluid in 13 patients with COPD (mean \pm SEM $67 \pm 2$ yrs, forced expiratory volume in one second (FEV 1 ) $61 \pm 4 \%$ reference), 16 smokers with normal lung function ( $55 \pm 2 \mathrm{yrs}, \mathrm{FEV}_{1} 97 \pm 4 \%$ reference) and seven never-smokers (67 \pm 7 yrs, FEV $194 \pm 4 \%$ reference). After sorting, AM were cultured (with and without lipopolysaccharide stimulation) after $4 \mathrm{~h}$ and $24 \mathrm{~h}$, and the concentrations of leukotriene $B_{4}$ $\left(\mathrm{LTB}_{4}\right)$, transforming growth factor (TGF) $\beta_{1}$ and tissue inhibitor of metalloproteinase (TIMP)-1 were quantified in the supernatant by ELISA. The production of reactive oxygen intermediates (ROI) in freshly isolated AM was determined by flow cytometry.

$\mathrm{LTB}_{4}$ secretion and ROI production were not different between groups. In contrast, AM from COPD patients released significantly less TGF- $\beta_{1}$ and TIMP-1 than those from smokers with normal lung function and nonsmokers.

In conclusion, these observations are compatible with reduced anti-inflammatory and antielastolytic capacity in chronic obstructive pulmonary disease, which is likely to contribute to the pathogenesis of the disease.

KEYWORDS: Chronic obstructive pulmonary disease, leukotrienes, oxidative stress, tissue inhibitor of metalloproteinase-1, transforming growth factor- $\beta_{1}$

$\mathbf{T}$ he inflammatory response to tobacco smoking is an essential pathogenic factor in chronic obstructive pulmonary disease (COPD) [1]. A variety of inflammatory cells, including alveolar macrophages (AM), polymorphonuclear (PMN) leukocytes and lymphocytes [2], and mediators such as cytokines, oxidants and matrix metalloproteinases (MMPs) participate in this response [2]. Given that tobacco smoking elicits an inflammatory response in all smokers [3], but only some of them develop COPD [4], it is likely that its type, intensity, localisation and/or failure to resolve after smoking cessation may contribute to the pathogenesis of the disease [5].

AM are ideally suited to control the degree and duration of the inflammatory response elicited by tobacco smoking because they are the major immunocompetent cell population in the lower human respiratory tract, where they act as sentinel cells [6]. In response to an inflammatory stimulus such as smoking, AM rapidly release the following: 1) cytokines, such as interleukin (IL)-8 and tumour necrosis factor- $\alpha$, which act in further recruiting PMNs that can, in turn, release more inflammatory mediators [7]; 2) leukotriene $\mathrm{B}_{4}\left(\mathrm{LTB}_{4}\right)$, a potent chemoattractant for other inflammatory cells [7]; 3 ) reactive oxygen intermediates (ROI) $[8,9]$, which can contribute towards enhancing the inflammatory response; and 4) MMP-1 and MMP-9, which can degrade the interstitial matrix and cause emphysema [7]. Conversely, AM also contribute to the resolution of the inflammatory response because they are capable of releasing several anti-inflammatory molecules, such as transforming growth factor (TGF)- $\beta$ and tissue inhibitors of MMPs (TIMPs) $[6,7]$. Previous studies in COPD have reported an abnormal release of IL-8, MMP-1 and MMP-9 by $A M$ in these patients [9-11]. In the present investigation, the hypothesis that AM harvested

\section{AFFILIATIONS}

*Serveis de Analisis Clinics,

\#Pneumologia, and

-Unitat de Investigació, Hospital Universitari Son Dureta, IUNICS (Institut Universitari d'Investigació en Ciències de la Salut), Palma de Mallorca, Spain.

CORRESPONDENCE

J. Sauleda

Servei Pneumologia

Hospital Universitari

Son Dureta

Andrea Doria 55

07014 Palma Mallorca

Spain

Fax: 34971175228

E-mail: jsauleda@hsd.es

Received:

March 172004

Accepted after revision

March 212005

SUPPORT STATEMENT

The study was supported, in part, by CICIYT (Comisión Interministerial de Ciencia y Tecnología, Madrid, Spain SAF 2001/0203), SEPAR (Sociedad Española de Patología del Aparato Respiratorio, Barcelona, Spain), Red Respira (Madrid, Spain; RTIC 03/11, Fondo de Investigación Sanitaria, Instituto de Salud Carlos III) and ABEMAR (Associació Balear per l'Estudi de les Malalties Respiratóries, Palma Mallorca, Spain). This study was presented partially as an abstract at ATS, ERS and SEPAR meetings in 2003 . 
from patients with COPD release more pro-inflammatory mediators $\left(\mathrm{LTB}_{4}, \mathrm{ROI}\right)$ and/or less anti-inflammatory molecules (TGF- $\beta_{1}$, TIMP-1) than those obtained from smokers with preserved lung function was tested.

\section{METHODS}

\section{Subjects and ethics}

The current authors studied 13 patients with COPD (four current and nine ex-smokers) as defined by the Global Initiative for Obstructive Lung Disease (GOLD) criteria [1], 16 active smokers without chronic bronchitis or dyspnoea and with normal lung function, and seven never-smokers. All required bronchoscopic evaluation of a solitary pulmonary nodule or a haemoptysis episode. All patients with COPD were clinically stable and had not had any exacerbations for at least the 3 months that preceded inclusion in the study. The patients were treated with inhaled bronchodilators (salmeterol and/or salbutamol and/or ipratropium bromide), and four patients were treated with inhaled corticosteroids (ICS), but none received oral steroids. Patients with other chronic lung diseases (e.g. asthma, bronchiectasis and interstitial lung diseases) and cardiac, hepatic or renal failure were excluded. All participants gave signed, informed consent. The Ethics Committee of Comite d'Etica de les Illes Balears (Palma Mallorca, Spain) approved the study protocol.

\section{Lung function}

A forced spirometry (GS; Warren E. Collins, Braintree, MA, USA) was obtained in all participants [12]. Spirometric reference values were those of a Mediterranean population [13]. Exhaled CO concentrations (ToxCO; Bedfont, Rochester, UK) were recorded before bronchoscopy to exclude active smoking.

\section{Bronchoscopy}

Bronchoscopy was performed with a flexible fibreoptic bronchoscope (Pentax 15v; Pentax, Tokyo, Japan). Active smoking subjects refrained from smoking for at least $12 \mathrm{~h}$ before bronchocopy. This was checked by the exhaled CO concentration, which was $<10 \mathrm{ppm}$ in all cases. Bronchoalveolar lavage (BAL) was performed following the standard methodology. Eight 25-mL aliquots of sterile saline solution were instilled in one pulmonary segment of one of the lower pulmonary lobes not containing any nodule. Aliquots were placed in plastic recipients and immediately centrifuged at $200 \times g$ for $10 \mathrm{~min}$ at $4^{\circ} \mathrm{C}$. The cell pellet was washed once in calcium- and magnesium-free Hank's balanced saline solution (Gibco BRL, Eggenstein, Germany) and resuspended in minimal essential medium (Gibco BRL) until sorting. Cells were counted with a haemocytometer. Viability determined by trypan blue exclusion was always $>95 \%$.

The presence of airway bacterial infection was excluded by using a protected specimen brush (PSB; Mill-Rose Lab, Mentor, $\mathrm{OH}, \mathrm{USA}$ ) to sample bronchial secretions sterilely before BAL [14]. The culture of PSB samples yielded $<10^{3}$ colony forming units $\mathrm{mL}^{-1}$ in all participants.

\section{Sorting of alveolar macrophages}

AM were sorted in BAL samples using a Coulter Epics Altra HyPerSort ${ }^{\mathrm{TM}}$ System (Beckman Coulter, Izasa, Spain). Calibration of the optical system was performed using flow-check fluorospheres (Beckman Coulter). Nozzle orifice, flow rate and sorting strategy were set up as previously described [15]. Briefly, a $100-\mu \mathrm{m}$ diameter flow cell tip was used and the flow rate was adjusted to $400-500$ events $\cdot \mathrm{s}^{-1}$. AM were gated on a forward scatter (linear scale) versus green fluorescence (logarithmic scale) to discriminate them, with a high degree of autofluorescence from neutrophils and lymphocytes. Cell suspensions, before and after sorting, were kept in polypropylene tubes and maintained on ice. After sorting, cells were counted in a haemocytometer and viability was determined by trypan blue exclusion. Cytospin preparations were prepared for morphological differentiation of BAL cells following Papanicolau staining. The purity of sorted AM was always $>96 \%$ as analysed by flow cytometry and visual quantification. Cell viability by trypan blue exclusion was always $>95 \%$.

\section{Macrophage culture}

Sorted AM were suspended at $5 \times 10^{5} \cdot \mathrm{mL}^{-1}$ in endotoxin-free RPMI $1640 / 10 \%$ foetal calf serum, supplemented with $2 \mathrm{mM}$ L-glutamine, $25 \mathrm{U} \cdot \mathrm{mL}^{-1}$ penicillin and $25 \mu \mathrm{g} \cdot \mathrm{mL}^{-1}$ streptomycin. Cells were separated into aliquots and cultured in 24-well polystyrene plates (Nunc, Wiesbaden, Germany) at $37^{\circ} \mathrm{C}$ and $5 \% \mathrm{CO}_{2}$ for $4 \mathrm{~h}$ and $24 \mathrm{~h}$, with or without lipopolysaccharide (LPS (O55:B5), $100 \mathrm{ng} \cdot \mathrm{mL}^{-1}$ (final concentration); Escherichia coli LPS; Sigma Chemicals CO, St. Louis, MO, USA). At these time points, the supernatant was collected and stored cell free at $-80^{\circ} \mathrm{C}$ until analysed.

\section{Measurement of TGF- $\beta$, TIMP and LTB 4}

The cell culture supernatant concentration of TGF- $\beta_{1}$, TIMP- 1 and $\mathrm{LTB}_{4}$ was measured using a commercially available sandwich ELISA kits (Amersham Pharmacia Biotech, Chalfont, UK). Biologically active TGF- $\beta_{1}$ was measured in previously acidified samples $(0.02 \mathrm{~mL}$ of $1-\mathrm{M}$ hydrochloric acid was added to $100 \mu \mathrm{L}$ of samples to achieve $\mathrm{pH} 1-2)$. $\mathrm{LTB}_{4}$ was measured using an enzyme-immunoassay system according to the manufacturer's directions (Amersham Pharmacia Biotech). The detection limits of TGF- $\beta_{1}$, TIMP- 1 and LTB $_{4}$ assays were $6 \mathrm{pg} \cdot \mathrm{mL}^{-1}, 15.6 \mathrm{pg} \cdot \mathrm{mL}^{-1}$ and $1.25 \mathrm{pg} \cdot \mathrm{mL}^{-1}$, respectively.

\section{Measurement of ROI}

Production of ROI by fresh AM was determined by flow cytometry through the formation of the fluorescent compound rhodamine-123 from dihydrorhodamine-123 (DHR; Molecular Probes, Eugene, OR, USA). In brief, two 200- $\mu$ L samples of the macrophage suspension $\left(5 \times 10^{5} \cdot \mathrm{mL}^{-1}\right.$; Falcon No. 2052; Beckton-Dickinson, Lincoln Park, NJ, USA) were incubated in polypropylene tubes with $10 \mu \mathrm{L}$ of a DHR solution $\left(100 \mu \mathrm{g} \cdot \mathrm{mL}^{-1}\right)$ for $10 \mathrm{~min}$ at $37^{\circ} \mathrm{C}$. One sample was used to assess the spontaneous ROI production, while the other was mixed with $20 \mu \mathrm{L}$ of LPS (10 $\mathrm{ng} \cdot \mathrm{mL}^{-1}$, final concentration). Both samples were incubated for $30 \mathrm{~min}$ at $37^{\circ} \mathrm{C}$. At the end of the second incubation period, $500 \mu \mathrm{L}$ of cold PBS was added to both samples, which were then kept on ice until analysed by flow cytometry on a Coulter Epics Altra HyPerSort ${ }^{\mathrm{TM}}$ System (Beckman Coulter) with a gate setting for macrophages on forward and side scatter. In total, 10,000 cells were analysed; green fluorescence was determined and mean cellular fluorescence intensities were calculated using LYSIS II software. Cell suspensions served as controls of autofluorescence. The 
intensity of the specific fluorescence was calculated and expressed as relative linear mean fluorescence (RLMF), the ratio of specific to nonspecific (autofluorescence) linear fluorescence.

\section{Statistical analysis}

Results are shown as mean \pm SEM. One-way ANOVA (followed by post hoc contrast (Scheffe) if appropriate) was used to assess the statistical significance of the differences between groups. To analyse the potential effects of ICS in patients with COPD, the Mann-Whitney U-test was used. Correlations between variables of interest were explored using the Spearman rank test. A p-value $<0.05$ was considered significant.

\section{RESULTS}

\section{Anthropometric and functional data}

Table 1 presents the main clinical and lung function data of all particpants. Age was similar in never-smokers and patients with COPD, but smokers with normal lung function were younger. Likewise, the latter had a smaller smoking exposure than patients with COPD (table 1). According to GOLD criteria, patients with COPD showed moderate airflow obstruction. By definition, spirometry was normal in smokers with normal lung function and never-smokers.

\section{BAL cell count}

Total cell count was higher in smokers with normal lung function $\left(3.6 \pm 0.6 \times 10^{5} \cdot \mathrm{mL}^{-1}\right)$ than in nonsmokers $\left(0.9 \pm 0.5 \times 10^{5} \cdot \mathrm{mL}^{-1} ; \mathrm{p}<0.05\right)$. Patients with COPD also showed a trend towards higher values $\left(2.1 \pm 0.5 \times 10^{5} \cdot \mathrm{mL}^{-1}\right)$, but differences failed to reach statistical significance. Differential cell counts were similar among groups (table 2). Nevertheless, the number of AM tended to be higher in smokers with normal lung function, and the number of neutrophils appeared to be increased in patients with COPD. Overall, these observations are in keeping with previous studies [16].

\section{$\mathrm{LTB}_{4}$ release}

After $4 \mathrm{~h}$ in culture, $\mathrm{LTB}_{4}$ levels were similar in nonsmokers $\left(222 \pm 107 \mathrm{pg} \cdot \mathrm{mL}^{-1}\right)$ and smokers with normal lung function

TABLE 1 Clinical and lung function data of all participants

$$
\text { Nonsmokers }
$$

Smokers with normal

COPD lung function

\begin{tabular}{lccc} 
Subjects n & 7 & 16 & 13 \\
Age yrs & $67 \pm 7$ & $55 \pm 2$ & $67 \pm 2^{\#}$ \\
Pack-yrs & 0 & $40 \pm 4^{\star \star}$ & $61 \pm 7^{\star \star *}$, \\
Active smokers & 0 & 16 & 4 \\
Ex-smokers & 0 & 0 & 9 \\
Inhaled steroids & 0 & 0 & 4 \\
FEV1 \% pred & $94 \pm 4$ & $97 \pm 4$ & $61 \pm 4^{\star *}$ \\
FEV1/FVC \% & $81 \pm 4$ & $81 \pm 2$ & $59 \pm 2^{\star} \#$ \\
\hline
\end{tabular}

Data are presented as mean \pm SEM. COPD: chronic obstructive pulmonary disease; FEV1: forced expiratory volume in one second; \% pred: \% predicted; FVC: forced vital capacity. *: $p<0.05$; ${ }^{*}: \mathrm{p}<0.01$ (versus nonsmokers); \#; $\mathrm{p}<0.05$ (versus smokers with normal lung function). Spirometric reference values were those of a Mediterranean population [13]

\begin{tabular}{|c|c|c|c|}
\hline \multirow[t]{2}{*}{ TABLE 2} & \multicolumn{3}{|c|}{$\begin{array}{l}\text { Bronchoalveolar lavage fluid total and differential } \\
\text { cell counts }\end{array}$} \\
\hline & Nonsmokers & $\begin{array}{l}\text { Smokers with normal } \\
\text { lung function }\end{array}$ & COPD \\
\hline Subjects $n$ & 7 & 16 & 13 \\
\hline $\begin{array}{l}\text { Total cell coun } \\
\times 10^{5} \cdot \mathrm{mL}^{-1}\end{array}$ & $0.9 \pm 0.5$ & $3.6 \pm 0.6^{*}$ & $2.1 \pm 0.5$ \\
\hline Macrophages & $90 \pm 5$ & $94 \pm 1$ & $90 \pm 2$ \\
\hline Lymphocytes \% & $7 \pm 5$ & $5 \pm 1$ & $7.5 \pm 1$ \\
\hline Neutrophils \% & $0.8 \pm 0.5$ & $0.8 \pm 0.2$ & $2.5 \pm 1$ \\
\hline
\end{tabular}

$\left(244 \pm 107 \mathrm{pg} \cdot \mathrm{mL}^{-1}\right)$. Patients with COPD showed a trend towards lower values $\left(137 \pm 61 \mathrm{pg} \cdot \mathrm{mL}^{-1}\right)$, but differences failed to reach statistical significance. LPS stimulation did not modulate these levels significantly (nonsmokers: $284 \pm 144 \mathrm{pg} \cdot \mathrm{mL}^{-1}$; smokers with normal lung function: $342 \pm 99 \mathrm{pg} \cdot \mathrm{mL}^{-1}$; patients with COPD: $\left.226 \pm 94 \mathrm{pg} \cdot \mathrm{mL}^{-1}\right)$. The current authors did not measure $\mathrm{LTB}_{4}$ release after $24 \mathrm{~h}$ in culture, as previous studies have shown that $\mathrm{LTB}_{4}$ is almost completely metabolised at this time point [17].

\section{ROI production}

ROI production was similar in nonsmokers (8.32 \pm 3.67 RLMF), smokers with normal lung function $(5.03 \pm 1.47 \mathrm{RLMF})$ and patients with COPD $(6.32 \pm 1.68 \mathrm{RLMF})$. LPS stimulation did not modify these values significantly (nonsmokers: $8.26 \pm 4.07$ RLMF; smokers with normal lung function: $5.29 \pm 1.60$ RLMF; patients with COPD: $6.37 \pm 1.69$ RLMF).

\section{TGF- $\beta_{1}$ release}

After $4 \mathrm{~h}$ in culture, TGF- $\beta_{1}$ concentration was below the detection limit of the assay in all groups. At $24 \mathrm{~h}$, TGF- $\beta_{1}$ levels were detectable and similar in all of them (fig. 1). The addition

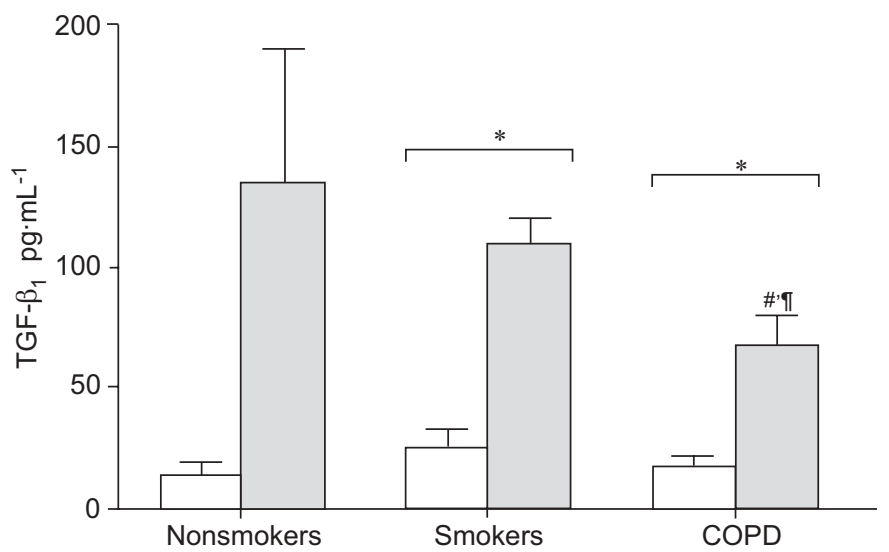

FIGURE 1. Transforming growth factor (TGF)- $\beta_{1}$ release after $24 \mathrm{~h}$ in culture in each of the subject groups studied, both with ( $\square$ ) and without $(\square)$ Escherichia coli lipopolysaccharide $\left(100 \mathrm{ng} \cdot \mathrm{mL}^{-1}\right)$ stimulation. COPD: chronic obstructive pulmonary disease. *: $p<0.05 ;{ }^{*}: p<0.01 ; *: p<0.05$ versus nonsmokers; $9: p<0.05$ versus smokers with normal lung function. 
of LPS increased TGF- $\beta_{1}$ release in all groups, but this effect was significantly attenuated in patients with COPD $\left(67 \pm 13 \mathrm{ng} \cdot \mathrm{mL}^{-1}\right)$ as compared with smokers with normal lung function $\left(135 \pm 55 \mathrm{ng} \cdot \mathrm{mL}^{-1} ; \quad \mathrm{p}<0.01\right)$ or nonsmokers $\left(110 \pm 10 \mathrm{ng} \cdot \mathrm{mL}^{-1} ; \mathrm{p}<0.05\right)$.

\section{TIMP-1 release}

After $4 \mathrm{~h}$ in culture, without LPS stimulation, AM from smokers with normal lung function released less TIMP-1 $\left(6.2 \pm 2.1 \mathrm{ng} \cdot \mathrm{mL}^{-1}\right) \quad$ than nonsmokers $\left(11.7 \pm 2.4 \mathrm{ng} \cdot \mathrm{mL}^{-1}\right.$; $\mathrm{p}<0.05)$. This defect was further accentuated in patients with COPD $\left(1.7 \pm 0.4 \mathrm{ng} \cdot \mathrm{mL}^{-1} ; \mathrm{p}<0.05\right.$ versus smokers with normal lung function; fig. 2). Stimulation with LPS augmented TIMP-1 release in nonsmokers $\left(16.7 \pm 4 \mathrm{ng} \cdot \mathrm{mL}^{-1} ; \mathrm{p}<0.05\right)$. Interestingly, this effect was clearly reduced in smokers with normal lung function $\left(6.2 \pm 2.1 \mathrm{ng} \cdot \mathrm{mL}^{-1}\right)$, and basically abolished in patients with COPD $\left(2.4 \pm 0.8 \mathrm{ng} \cdot \mathrm{mL}^{-1}\right)$. At $24 \mathrm{~h}$, TIMP-1 release increased significantly in all groups (note change of $y$-axis scale in fig. 2). LPS stimulation did not enhance TIMP-1 release any further in any group, but differences observed at $4 \mathrm{~h}$ between groups persisted. Hence, TIMP-1 release was significantly lower in smokers with normal lung function and almost absent in patients with COPD (fig. 2).
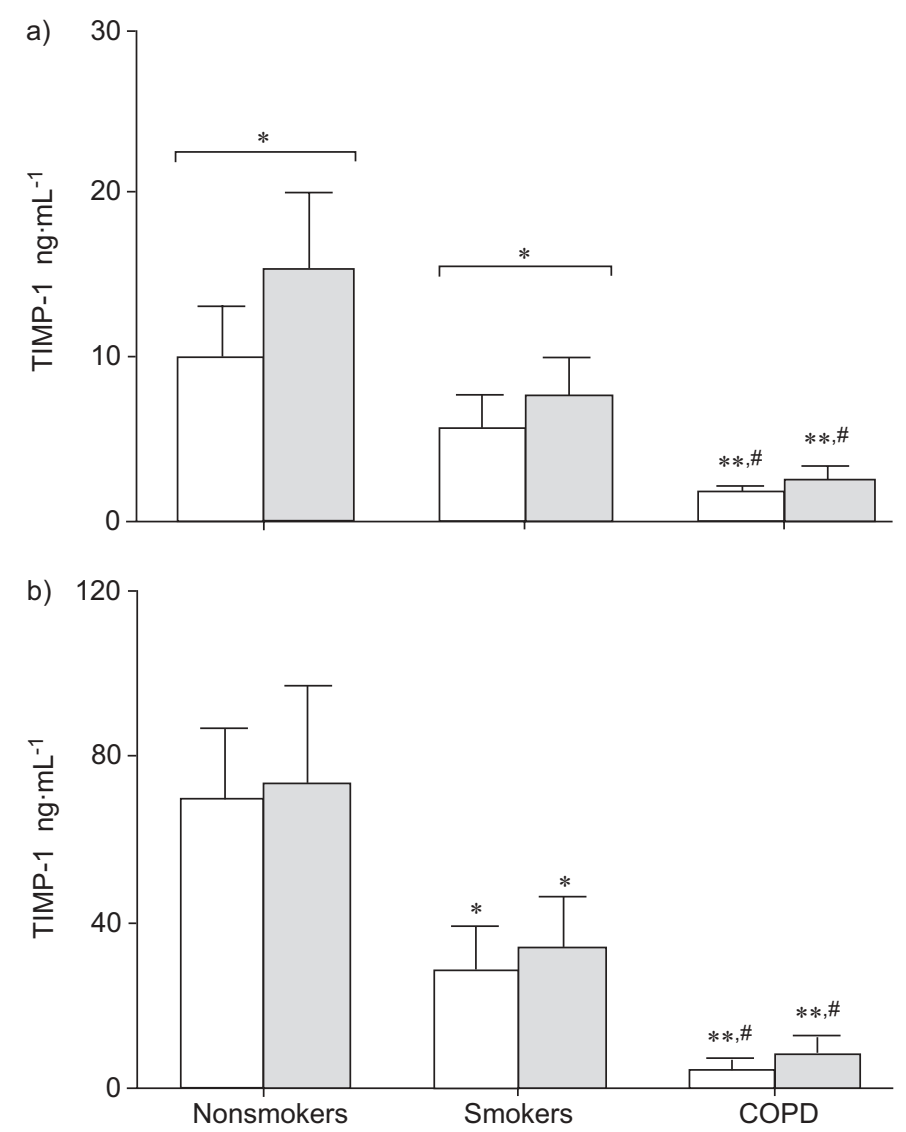

FIGURE 2. Tissue inhibitor of metalloproteinase (TIMP)- 1 release after a) $4 \mathrm{~h}$, and b) $24 \mathrm{~h}$ in culture in each of the subject groups studied, both with ( $\square$ ) and without $(\square)$ Escherichia coli lipopolysaccharide $\left(100 \mathrm{ng} \cdot \mathrm{mL}^{-1}\right)$ stimulation. COPD: chronic obstructive pulmonary disease. ${ }^{*}: p<0.05 ;{ }^{*}$ : $p<0.01$ versus nonsmokers; $\#: p<0.05$ versus smokers with normal lung function.

\section{Effect of ICS}

$\mathrm{LTB}_{4}, \mathrm{TGF}-\beta_{1}$, TIMP-1 and ROI production were not different at any time point in patients treated with $(n=4)$ or without ICS $(\mathrm{n}=9)$.

\section{Physiological correlates}

As smokers with normal lung function were younger and had smoked less than patients with COPD (table 1), in order to investigate a potential confounding effect of these two variables upon the different mediators studied, the biological relationships between the former and the latter were explored. However, no significant relationship could be found.

\section{DISCUSSION}

Tobacco smoking is the major risk factor for COPD [1]. However, only a small percentage of smokers develop the disease [2]. An excessive and persistent inflammatory response appears to be the hallmark of these latter individuals [5]. In theory, this can be due either to an enhanced inflammatory response to tobacco smoking and/or a failure to switch off the inflammatory machinery when the stimuli cease [5]. AM are the major immunocompetent cell population in the lower human respiratory tract and, as such, they are likely to play a significant role in the initiation, modulation and eventual termination of the inflammation that follows cigarette smoking [7]. In this study, the capacity of AM to secrete both pro- $\left(\mathrm{LTB}_{4}\right.$, ROI) and anti-inflammatory molecules (TGF- $\beta_{1}$ and TIMP-1) in patients with COPD was investigated. It was found that AM from these patients released similar amounts of $\mathrm{LTB}_{4}$ and ROI than those from smokers with preserved lung function or nonsmokers. In contrast, the released TGF- $\beta_{1}$ and TIMP- 1 by AM were markedly impaired in COPD.

$\mathrm{LTB}_{4}$ is increased in breath condensate [18], induced sputum [18] and serum [19] of patients with COPD. However, AM release of $\mathrm{LTB}_{4}$ has not been previously investigated in these patients. An abnormal release of $\mathrm{LTB}_{4}$ by $\mathrm{AM}$ in COPD was not observed. This is similar to that reported by SPENCER et al. [20] in $\mathrm{AM}$ from patients with $\alpha$-antitrypsin deficiency, and suggests that the main cellular source of $\mathrm{LTB}_{4}$ in COPD is a different cell type, perhaps the neutrophil [21]. This is not to say that AM are not important sources of other inflammatory mediators in COPD, such as IL-8 [9].

Oxidative stress is an important factor in the pathogenesis of COPD [22], and AM can produce ROI [6]. A previous study by MCLEOD et al. [23] could not detect significant differences in superoxide anion release by AM harvested from smokers with and without COPD. The results of the present study support this previous observation and, hence, also suggest a marginal role for $\mathrm{AM}$ in the pathogenesis of the oxidative stress that characterises COPD.

TGF- $\beta_{1}$ is a potent anti-inflammatory cytokine produced by several cell lineages, including AM [24-29]. It also has important anti-elastolytic properties because it reduces the production of MMP [30], and stimulates that of TIMP-1 and matrix proteins [31]. The current authors observed that AM from patients with COPD released significantly lower concentrations of TGF- $\beta_{1}$ in response to LPS than smokers with preserved lung function and never-smokers (fig. 1). To the present authors' knowledge, this has not been previously 
reported. Previous studies have reported increased expression of TGF- $\beta_{1}$ in the airway epithelium of patients with chronic bronchitis or COPD [32, 33]. None, however, analysed its release by AM. Differences between the current study and those previously can be related to the different cell lineages analysed and techniques used. Studies in bronchial epithelium tissue used in situ hybridisation and/or immunochemistry to ascertain cell-associated proteins, which may give different results [32, 33], whereas, in the current study, ELISA was used to determine TGF- $\beta_{1}$ levels in the supernatant. Furthermore, it is also possible that the airway epithelium and AM behave differently in terms of TGF- $\beta_{1}$ release in COPD. The increased expression of TGF- $\beta_{1}$ in the epithelium may reflect the relevance of this cytokine in airway remodelling in COPD [34]. In contrast, the decreased release of TGF- $\beta_{1}$ from AM may reflect a deficient anti-inflammatory/repair capacity of these cells in patients with COPD. The different behaviour of airway epithelium and AM in patients with COPD has also been reported for other cytokines [35]. Interestingly, a polymorphism of the TGF- $\beta_{1}$ gene that is associated with low TGF- $\beta_{1}$ levels is common in patients with COPD [36]. This observation would be in keeping with the current findings of reduced TGF$\beta_{1}$ release by AM in COPD patients.

Likewise, it was also observed that AM from patients with COPD release less TIMP-1 than those from smokers with normal lung function or nonsmokers (fig. 2). As TGF- $\beta_{1}$ stimulates TIMP-1 release [31], it is tempting to speculate that the lower TIMP-1 release seen in COPD may be mechanistically linked to the reduced TGF- $\beta_{1}$ release discussed previously. In any case, given that TIMP-1 is an important anti-elastolytic molecule [10], its reduced release in COPD may contribute to the development of pulmonary emphysema. However, the present results contrast with a previous study reporting no difference in TIMP-1 release by AM between COPD patients and smokers with normal lung function [10]. Several methodological aspects may contribute towards explaining this difference because, at variance with this former study [10], the current authors were very careful at controlling the acute effects of smoking known to cause oxidative stress and to decrease TIMP-1 activity [37]. An uneven distribution of active smokers in the individuals studied [10] may have blurred potential differences between groups. Likewise, at variance with previous studies [10, 11], bronchial infection was systemically excluded because it enhances lung inflammation [38].

Other methodological aspects of the current study also deserve comment. First, patients with COPD were not perfectly matched to smokers with normal lung function in terms of age and smoking history. However, the absence of any significant relationship between these two variables and any of the biological mediators studied here suggests that the relatively small differences (albeit statistically significant) of both age and smoking history did not exert any relevant confounding effects. Secondly, no significant differences were found in BAL cell counts between patients with COPD and smokers with normal lung function. This is in keeping with some previous studies [16], and in contrast to others [10], suggesting a high variability of the inflammatory cell counts in these subjects. Thirdly, previous studies isolated AM attending to their adherent properties [10, 11], whereas the present authors used flow-sorted AM. This strategy avoids the loss of nonadhering AM [39], although it does not prevent the priming of the adherent ones, because, for the duration of the exposition period, the cells were cultured in plastic well plates and may have presumably also adhered to the plastic surface. Fourthly, previous reports incubated AM $24 \mathrm{~h}$ before stimulation $[9,10,40]$. As mentioned earlier, this can alter AM response [39]. Accordingly, the present authors decided to stimulate AM immediately after sorting and to quantify the concentration of the different inflammatory mediators both early $(4 \mathrm{~h})$ and late $(24 \mathrm{~h})$. Fifthly, the concentration of LPS used and the time points chosen were similar to those of previous studies $[10,41,42]$. However, different results in $\mathrm{LTB}_{4}$ and/or ROI release may have been found if different LPS concentrations and/or different time points had been used [17, 41]. Sixthly, the current authors did not analyse other inflammatory markers that might be relevant in COPD, such as IL-8 and MMP-9. This was because previous studies have already done so $[9,43]$, and the present authors wanted to focus on other less well-characterised molecules. Finally, the current authors excluded a potential confounding effect of ICS because there were no significant differences in the levels of the mediators studied between patients with $(n=4)$ and without ICS $(n=9)$. This is in keeping with many studies suggesting a relative steroid resistance in COPD [44-46].

In conclusion, the present study shows that alveolar macrophages in chronic obstructive pulmonary disease release significantly less transforming growth factor- $\beta_{1}$ and tissue inhibitor of metalloproteinase- 1 than smokers with preserved lung function and never-smokers. This observation suggests a lower anti-inflammatory and anti-proteolytic activity in these patients that may, eventually, contribute to the pathogenesis of the disease.

\section{ACKNOWLEDGEMENTS}

The authors would like to thank the participating individuals for their collaboration, and F. Bauzà, M. Bosch, A. Noguera and M. López for their help during the study.

\section{REFERENCES}

1 Pauwels R, Buist AS, Calverley PMA, Jenkins CR, Hurd S, on behalf of the GOLD scientific committee. Global strategy for the diagnosis, management and prevention of chronic pulmonary disease. NHLBI/WHO Global Initiative for Chronic Obstructive Lung Disease (GOLD). Workshop summary. Am J Respir Crit Care Med 2001; 163: 1256-1276.

2 Barnes PJ. Chronic obstructive pulmonary disease. N Engl J Med 2000; 343: 269-280.

3 Hogg JC. Pathophysiology of airflow limitation in chronic obstructive pulmonary disease. Lancet 2004; 364: 709-721.

4 Fletcher C, Peto R. The natural history of chronic airflow obstruction. BMJ 1977; 1: 1645-1648.

5 Agusti A, MacNee W, Donaldson K, Cosio M. Hypothesis: does COPD have an autoimmune component? Thorax 2003; 58: 832-834.

6 Lohmann-Matthes ML, Steinmuller C, Franke-Ullmann G. Pulmonary macrophages. Eur Respir J 1994; 7: 1678-1689.

7 Shapiro SD. The macrophage in chronic obstructive pulmonary disease. Am J Respir Crit Care Med 1999; 160: S29-S32. 
8 Nathan C. Points of control in inflammation. Nature 2002; 420: 846-852.

9 Culpitt SV, Rogers DF, Shah P, et al. Impaired inhibition by dexamethasone of cytokine release by alveolar macrophages from patients with chronic obstructive pulmonary disease. Am J Respir Crit Care Med 2003; 167: 24-31.

10 Russell RE, Culpitt SV, DeMatos C, et al. Release and activity of matrix metalloproteinase- 9 and tissue inhibitor of metalloproteinase- 1 by alveolar macrophages from patients with chronic obstructive pulmonary disease. Am J Respir Cell Mol Biol 2002; 26: 602-609.

11 Finlay GA, O’Driscoll LR, Russell KJ, et al. Matrix metalloproteinase expression and production by alveolar macrophages in emphysema. Am J Respir Crit Care Med 1997; 156: 240-247.

12 American Thoracic Society Official Statement. Standardization of spirometry. 1994 Update. Am J Respir Crit Care Med 1995; 152: 1107-1136.

13 Roca J, Sanchis J, Agustí-Vidal A, et al. Spirometric reference values for a Mediterranean population. Bull Eur Physiopathol Respir 1986; 22: 217-224.

14 Wimberley NW, Bass JB Jr, Boyd BW, Kirkpatrick MB, Serio RA, Pollock HM. Use of a bronchoscopic protected catheter brush for the diagnosis of pulmonary infections. Chest 1982; 81: 556-562.

15 Maus U, Rousseau S, Seeger W, Lohmeyer J. Separation of human alveolar macrophages by flow cytometry. Am J Physiol 1997; 272: L566-L571.

16 Linden M, Rasmussen JB, Pitulainen E, et al. Airway inflammation in smokers with nonobstructive and obstructive chronic bronchitis. Am Rev Respir Dis 1993; 148: 1226-1232.

17 Rankin JA, Sylvester I, Smith S, Yoshimura T, Leonard EJ. Macrophages cultured in vitro release leukotriene B4 and neutrophil attractant/activation protein (interleukin 8) sequentially in response to stimulation with lipopolysaccharide and zymosan. J Clin Invest 1990; 86: 1556-1564.

18 Montuschi P, Kharitonov SA, Ciabattoni G, Barnes PJ. Exhaled leukotrienes and prostaglandins in COPD. Thorax 2003; 58: 585-588.

19 Seggev JS, Thornton WH Jr, Edes TE. Serum leukotriene B4 levels in patients with obstructive pulmonary disease. Chest 1991; 99: 289-291.

20 Spencer LT, Paone G, Krein PM, Rouhani FN, RiveraNieves J, Brantly ML. Role of human neutrophil peptides in lung inflammation associated with alpha1-antitrypsin deficiency. Am J Physiol Lung Cell Mol Physiol 2004; 286: L514-L520.

21 Zhou S, Stark JM, Leikauf GD. Leukotriene B4 formation: human neutrophil-airway epithelial cell interactions. J Appl Physiol 1995; 78: 1396-1403.

22 MacNee W. Oxidants/antioxidants and COPD. Chest 2000; 117: Suppl. 1, 303S-317S.

23 McLeod R, Mack DG, McLeod EG, Campbell EJ, Estes RG. Alveolar macrophage function and inflammatory stimuli in smokers with and without obstructive lung disease. Am Rev Respir Dis 1985; 131: 377-384.

24 Shull MM, Ormsby I, Kier AB, et al. Targeted disruption of the mouse transforming growth factor-beta 1 gene results in multifocal inflammatory disease. Nature 1992; 359: 693-699.
25 Kulkarni AB, Huh CG, Becker D, et al. Transforming growth factor beta 1 null mutation in mice causes excessive inflammatory response and early death. Proc Natl Acad Sci USA 1993; 90: 770-774.

26 Yaswen L, Kulkarni AB, Fredrickson T, et al. Autoimmune manifestations in the transforming growth factor-beta 1 knockout mouse. Blood 1996; 87: 1439-1445.

27 Letterio JJ, Roberts AB. Regulation of immune responses by TGF-beta. Annu Rev Immunol 1998; 16: 137-161.

28 Christ M, McCartney-Francis NL, Kulkarni AB, et al. Immune dysregulation in TGF-beta 1-deficient mice. J Immunol 1994; 153: 1936-1946.

29 Nakao A, Miike S, Hatano M, et al. Blockade of transforming growth factor beta/Smad signaling in $\mathrm{T}$ cells by overexpression of Smad7 enhances antigen-induced airway inflammation and airway reactivity. J Exp Med 2000; 192: 151-158.

30 Feinberg MW, Jain MK, Werner F, et al. Transforming growth factor-beta 1 inhibits cytokine-mediated induction of human metalloelastase in macrophages. J Biol Chem 2000; 275: 25766-25773.

31 Border WA, Noble NA. Transforming growth factor beta in tissue fibrosis. N Engl J Med 1994; 331: 1286-1292.

32 Vignola AM, Chanez P, Chiappara G, et al. Transforming growth factor-beta expression in mucosal biopsies in asthma and chronic bronchitis. Am J Respir Crit Care Med 1997; 156: 591-599.

33 De Boer WI, van Schadewijk A, Sont JK, et al. Transforming growth factor $\beta_{1}$ and recruitment of macrophages and mast cells in airways in chronic obstructive pulmonary disease. Am J Respir Crit Care Med 1998; 158: 1951-1957.

34 Jeffery PK. Remodeling in asthma and chronic obstructive lung disease. Am J Respir Crit Care Med 2001; 164: S28-S38.

35 Fuke S, Betsuyaku T, Nasuhara Y, Morikawa T, Katoh H, Nishimura M. Chemokines in bronchiolar epithelium in the development of chronic obstructive pulmonary disease. Am J Respir Cell Mol Biol 2004; 31: 405-412.

$36 \mathrm{Wu} \mathrm{L}$, Chau J, Young RP, et al. Transforming growth factor-beta1 genotype and susceptibility to chronic obstructive pulmonary disease. Thorax 2004; 59: 126-129.

37 Frears ER, Zhang Z, Blake DR, O'Connell JP, Winyard PG. Inactivation of tissue inhibitor of metalloproteinase- 1 by peroxynitrite. FEBS Lett 1996; 381: 21-24.

38 Soler N, Ewig S, Torres A, Filella X, Gonzalez J, Zaubet A. Airway inflammation and bronchial microbial patterns in patients with stable chronic obstructive pulmonary disease. Eur Respir J 1999; 14: 1015-1022.

39 Bauer GJ, Arbabi S, Garcia IA, deHingh I, Rosengart MR, Maier RV. Adherence regulates macrophage signal transduction and primes tumor necrosis factor production. Shock 2000; 14: 435-440.

40 Finlay GA, Russell KJ, McMahon KJ, et al. Elevated levels of matrix metalloproteinases in bronchoalveolar lavage fluid of emphysematous patients. Thorax 1997; 52: 502506.

41 Suzuki K, Yamamoto T, Sato A, et al. Lipopolysaccharide primes human alveolar macrophages for enhanced release of superoxide anion and leukotriene B4: self-limitations of the priming response with protein synthesis. Am J Respir Cell Mol Biol 1993; 8: 500-508. 
42 Gosset $\mathrm{P}$, Wallaert B, Tonnel AB, Fourneau C. Thiol regulation of the production of TNF- $\alpha$, IL- 6 and IL- 8 by human alveolar macrophages. Eur Respir J 1999; 14: 98-105.

43 Lim S, Roche N, Oliver BG, Mattos W, Barnes PJ, Fan CK. Balance of matrix metalloprotease- 9 and tissue inhibitor of metalloprotease-1 from alveolar macrophages in cigarette smokers. Regulation by interleukin-10. Am J Respir Crit Care Med 2000; 162: 1355-1360.

44 Keatings VM, Jatakanon A, Worsdell YM, Barnes PJ. Effects of inhaled and oral glucocorticoids on inflammatory indices in asthma and COPD. Am J Respir Crit Care Med 1997; 155: 542-548.

45 Hattotuwa KL, Gizycki MJ, Ansari TW, Jeffery PK, Barnes NC. The effects of inhaled fluticasone on airway inflammation in chronic obstructive pulmonary disease: a double-blind, placebo-controlled biopsy study. Am J Respir Crit Care Med 2002; 165: 1592-1596.

46 Barnes PJ, Ito K, Adcock IM. Corticosteroid resistance in chronic obstructive pulmonary disease: inactivation of histone deacetylase. Lancet 2004; 363: 731-733. 